\title{
DIE ADOLESSENTE STUDENT
}

\author{
(Prof J Pieterse D. Phil (Pret)
}

\author{
Direkteur Studenteburo - Universiteit van Pretoria)
}

\begin{abstract}
(Referaat gelewer by dosente simposium. Aspekte van Tersiêre Onderrig, Departement Verpleegkunde, Universiteit van Pretoria. 4 Julie 1980)
\end{abstract}

\section{Inieiding}

$\mathbf{O}$ by 'n dosentesimposium oor aspekte van tersiêre onderrig ook oor die adolessente student te besin, is geen toevallige keuse nie. Om sinvol te kan onderrig, moet tog seker eerstens geweet word wie onderrig moet word. Daarom sal in hierdie referaat eerstens verwys word na adolessensie as lewensfase waartydens ook aandag gegee sal word aan die sogenaamde kultuurpuberteit. Daarna moet ook na die adolessente student as mens verwys word, waarna onderskeidelik die psigiese en geestelike aspekte asook enkele fisiese aspekte van adolessensie behandel sal word. Ten slotte sal die problematiek wat die adolessente student i.v.m. vrees vir mislukking ervaar, behandel word.

\section{Adolessensie as lewensfase}

Wanneer na adolessensie as lewensfase verwys word, moet dit allermins as ' $n$ verouderde faseologiese standpunt van vasomlynde fases gesien word. Nietemin weet ons dat die mens se lewe in twee groot tydperke of fases verdeel kan word - die kinderjare en die grootmensjare. Die jeugtydperk is min of meer die jare tussen hierdie twee fases - die tydperk van op-weg-navolwassendheid - wat gerieflikheidshalwe in puberteit en adolessensie ingedeel kan word, alhoewel ook hierdie twee tydperke nie in absolute sin geskei kan word nie en van mens tot mens verskil. Puberteit, die jare van geslagtelike rypwording, word gewoonlik as die tydperk van ongeveer 12,13,14 en miskien tot selfs 17 jaar gestel. Adolessensie, die tydperk wat volg op die puberteit, en wat in meerdere mate 'n tydperk van psigiese ryping is, val tussen die jare 17 tot 23 , alhoewel sommige sielkundiges en opvoedkundiges dit selfs tot op 25 jaar stel. Eintlik vorm puberteit en adolessensie in so 'n mate 'n verbandhoudende geheel, dat die een nie sonder verwysing na die ander behandel kan word nie.

\section{Die sogenaamde kultuurpuberteit}

Daarop moet ook op gewys word dat die proses van volwassewording as gevolg van die nuwe sosiale kragte van 'n industriële stadsmaatskappy en die verlengde lewensduur van die mens, 'n langer en 'n uitgerekter proses as in vorige dekades geword het(Nel, p.89).
In die primitiewe maatskappy het die psigiese puberteit feitlik glad nie bestaan nie en het die geslagtelike rypwording dus eintlik volwassenheid beteken. By die agrariese vorm van maatskappy is die kind so gou moontlik in die werk van die gesinsgroep ingeskakel en is sy volwassenheid bespoedig. In die industriële stadsmaatskappy het die kind egter 'n langer oefentydperk nodig om sy plek buite die gesinsgroep in te neem.

As gevolg van hierdie verskynsel van "kultuurpuberteit" word die tydperk yan adolessensie, die ontwikkeling wat volg op die puberteit tans meermale op die jare tussen 18 en 25 gestel - veel hoër as wat vroeër algemeen aanvaar is. In Nederland word byvoorbeeld aandag geskenk aan sogenaamde lewenskole vir werkende adolessente om hul koers en rigting in hul volwassenwordingsproses te gee.

Hierdie vertraagde volwassenheid word natuurlik ook veral in die hand gewerk deur die kloof of kluturele gaping, "cultural gap", wat teenswoordig tussen die jonger en die ouer geslag bestaan. In hierdie verband wys prof $\mathrm{J} \mathrm{H}$ van den Berg, die wêreldberoemde fenomenoloog daarop dat dit in die eerste instansie nie die kind nie, maar die volwassene en die wêreld van die volwassene is wat verander en sodanige gaping veroorsaak het. Hierdie verandering is volgens hom veral drieërlei van aard. (Kruk, pp.15-16).

Eerstens moet die oorsaak veral gesoek word in "het polyvalent worden van vele maatschappelijke instellingen." Tereg skryf hy soos volg: "Elke behandeling, elke zaak en daarmee elk woord bezitten niet éen maar steeds vele betekenissen. Het kind, dat naar deze pluriforme en polyvalente volwassenheid toegroeit, ontmoet haast onoverkomelijke moeilijkheden. Elke stap, die het doet om volwassen te worden, is een stap in de mist der polyvalenties".

In die tweede plek is die "onsigbaarheid van die volwasse staat" 'n oorsaak van die vertraagde volwassewording. Die kind sien steeds minder van die lewe van die volwassene, veral op die gebied van die arbeid en die seksuele lewe. Geen duidelike norme word gestel nie. 
Derdens moet as oorsaak gesien word die verandering in die wêreldbeeld. Die vanselfsprekendheid het uit die lewe verdwyn. Ons leef in 'n gerasionaliseerde wêreld, aanvaar nie meer die verskynsel as sodanig nie en probeer alles verklaar. En hierdie wêreld is vir die kind en jeugdige ontoeganklik en daarom word die kloof tussen jeugdige en volwassene nog groter.

\section{Die adolessente student as mens}

Heel aan die begin het ek gestel dat dit ook noodsaaklik is om na die adolessente student as mens te verwys, met ander woorde om ' $n$ bepaalde mensbeskouing te stel. Wat 'n mensbeskouing in die algemeen betref, en dus ook ' $n$ beskouing van die adolessente student as mens in die besonder, is ons as Christene se uitgangspunt dat die mens ' $n$ skepsel van God is, en wel in 'n heel besondere sin, naamlik dat hy na die beeld van God geskape is en dat sy bestemming op God gerig is. (Cronje, pp.1-2).

Daarom moet elke mens, ook elke student, met eerbeid en agting bejeën word - nie bloot omdat hy mens is nie, maar by uitstek omdat hy skepsel en beelddraer van God is.

Die mens is 'n fisiese, psigiese, geestelike wese. Die mens is van meet af aan ook 'n geestelike wese, en dus ook daartoe in staat om geestelike waardes sy eie te maak. Om hierdie rede is die mens nie net ' $n$ individu, of ondeelbare geheel nie, maar ook 'n persoon. En die persoon is die geestelike kernpunt van die menslike individu wat hom gedurigdeur in bepaalde werklike omstandighede bevind waarby hy hom moet inskakel, en hierdeur ontwikkel hy tot 'n persoonlikheid. Hy kom voortdurend in situasies waarin hy keuses moet maak. Hy is egter vry om te kies soos hy wil, maar wel vry tot verantwoordelikheid. (Nel, pp.14-18).

Dit is juis die menslike persoonlikheid, die geestelike kern wat die mens kan verhinder om 'n massamens te word. Anders as die psigo-analiste wat menswees meermale slegs as gedrewe-wees beskou, beskou die Christen mens-wees as verantwoordelik-wees.

Die proses van massifikasie, waardeur die massamens tot stand kom, beteken verlies van persoonlikheid. Waar jy dus as persoon en tot persoonlikheid opgevoed is, dus as 'n mens wat geestelike waardes sy eie gemaak het, het die massafikasieproses die uitwerking dat die mens van hierdie geestelike waardes begin prysgee. Die massajeug is die jeug wat 'n sekere vormloosheid en 'n gebrek aan persoonlikheid besit, wat gekenmerk word deur 'n gebrek aan bindinge en aan waardes, en wat minderwaardigheidsgevoelens het.

\section{Psigiese en Geestelike Aspekte}

Wanneer nou aandag gegee word aan die psigiese en geestelike aspekte van die adolessente student, is die bedoeling nie om die twee begrippe geheel en al van mekaar te skei nie, maar ek wil hulle tog onderskei in die sin dat die psigiese meer in die besonder te make het met aspekte soos die wilslewe, temperament, gevoel en intellek, terwyl die geestelike meer te make het met die eties-godsdienstige of religieuse.

Ook wat die psigiese lewe betref, is die adolessensie- tydperk 'n oorgangstydperk, en om die psigiese lewe van die jongmens te deurvors en te verstaan, is 'n moeilike taak. Liggaamlike veranderinge en verskeie ander faktore vertroebel sy gemoedslewe en maak dit vir hom moeilik om die geestesbelewing en gemoedstemminge met ander te bespreek. Dit is die jare waarin die jongmens sy verlore ewewig moet herwin, waarin gestreef word na sekerheid en selfstandigheid. Dit is die tyd van soeke en twyfel - 'n waardesin moet ontwikkel - helderheid moet verkry word aangaande fundamentele lewenswaardes, en 'n lewensbeskouing moet vasgelê word. Omdat die jongmens homself teenoor die lewe probeer oriënteer, wonder hy dikwels oor die sin van die lewe. Die jongmens se lewe word na binne gerig - hy ontwikkel 'n innerlike lewe wat hy self nie verstaan en begryp nie, en wat hy te bang is om aan die buitewêreld te vertoon.

Terselfdertyd ontdek hy homself - dit word die ontdekking van die "Ekheid"' genoem. En hy probeer in ander ook daardie menslike waarvan hy so pas in homself var. bewus geword het, vind - om dan so dikwels ontnugter en teleurgestel te word.

Gepaard hiermee gaan ook die ontwakende besef van die behoefte aan die teenoorgestelde geslag, wat vir hom baie psigiese spanninge en skuldgevoelens besorg.

Gedurende die jeugjare raak die mens ook meer krities teenoor dinge. Hy ontwikkel 'n eie opvatting en duld geen teenstand nie. Die gevolg is dat daar dikwels tussen hom en die gemeenskap wrywing ontstaan.

In hierdie verband is dit belangrik om daarop te wys dat daar ten opsigte van die mate waarin die gesin die kind skool en afrig vir die lewe, aansienlike veranderinge ingetree het. (Nel, pp.34-99). Waar die lewe buite die gesin vroeër eintlik 'n voortsetting van die gesinsverhoudinge was, is die samelewing vandag nie meer 'n strukturele kontinuïteit nie. Aan die een kant word die intieme gesinslewe aangetref en aan die ander kant die onpersoonlike samelewing wat beheer word deur die beginsel van rasionalisasie en organisasie. Daarom word die konflikte nie meer in die eerste plek in die gesin aangetref en "deurgewerk" nie, maar ontstaan dit tussen jeugdige en samelewing.

Hierdie verskynsel word ook volgens die Duitse sosioloog, Schelsky, in die hand gewerk deur die verdwyning van die patriargale gesinstruktuur en van die wesenskenmerke van hierdie struktuur. In die moderne gesin het die patriargale stelsel plek gemaak vir 'n toestand van gelykberegting. Aan die een kant het die outoritêre vaderfiguur verdwyn, veral in die boonste maatskaplike lae, en aan die ander kant het die moeder op die voorgrond getree. Hiermee verdwyn dan ook die so belangrike konfliksituasie wat veral in die vorm van opstand van die seun teen die vader, wat die maatskaplike eise verteenwoordig, ontstaan het. En met die verdwyning van hierdie proteshouding van die jeug in die gesin, gaan ook die verdwyning van die identifikasiehouding van jeugdiges met die outoritêre vaderfiguur gepaard.

Elke kind en jeugdige wat op opvoeding aangewys is, het ook behoefte aan gesag en leiding en dus ook behoefte aan 'n identifikasiefiguur. "Ten spyte van die vroeëre konfliksituasie in verband met die vaderfiguur 
... of, sal ons sê juis as 'n gevolg daarvan, . . . het die kind $t o g$ en veral lewensekerheid besit in die huis sowel as in die samelewing". (Nel, p.36). Waar daar nou 'n behoefte by die jeug aan identifikasie bestaan, soek hul die identifikasie buite die huis, en meermale onder die massajeug.

Waar jeugdiges vroeër oor te veel gesag gekla het, is hul klagte vandag teen te min gesag - een van die redes waarom jeugdiges ook nie meer in dieselfde mate aan hul huise gebind is nie en waarom hulle hul behoeftes buite die huis wil bevredig. Gepaard hiermee gaan die protes van die jeug teen die oorgefunksionaliseerde en oorgeorganiseerde samelewing wat ook in die gesinslewe ingedra word. "By die jeug", so skryf Nel, "is daar 'n ontvlugting van die oororganisasie, oorfunksionalisasie, die gejaagdheid, die gebrek aan leiding en gesag in die gesin en daarom bevind hulle hulself op straat, waar hul besig is om 'n eie lewenshouding, 'n eie subkultuur te skep'". (Nel, p.36).

Schelsky noem hierdie na-oorlogse jeug die "skeptiese geslag". Hy wys ook tereg daarop dat uit die kameraadskaplike gelykberegtigde verhoudinge wat met die verdwyning van die outoritêre vaderfiguur geskep is die bespreking van pynlike onderwerpe wat moontlik juis die probleme vir jeugdiges skep, vermy word, ten einde die "goeie verstandhouding" in die gesin te bly behou. Hierdeur word, wat Schelsky noem die "tipiese geslotenheid" van die moderne jeug veroorsaak ... hul gesels nie maklik met hul ouers of ander oor hul probleme nie. (Nel B F, p.38).

Die grootste enkele krisis vir die laat adolessent is waarskynlik: om 'n eie identiteit te vind en om dit te realiseer. Hy wil weet wie en wat hy is en watter betekenis hy in hierdie lewe het. Vir die vorming van 'n eie identiteit is die individu aangewese op sy medemens, sy integrasie van waardestelsels, godsdiens, seksualiteit en kulturele norme. Indien ' $n$ individu hom vroeër in sy ouerhuis in 'n relatief afgebakende en beskermende omgewing bevind het, is hierdie faktore ook beperk afgebaken en relatief stereotiep.

Hy het, met ander woorde, met 'n beskermende omgewing te doen waar sy identiteit feitlik vir hom op 'n skinkbord gegee word. Indien hy hom later in 'n meer amorfe sosiale struktuur van 'n universiteit sou bevind, is ook waardes, norme, godsdiensvorme en interpersoonlike verhoudings van 'n minder stereotiepe en meer heterogene aard. Hierdie struktuur kan uit die aard van die saak nie meer sy identiteit vir hom gee nie en hy is dan aangewese op reeds geïntegreerde en geïnternaliseerde waardestelsels, norme en interpersoonlike verhoudings. Indien hierdie faktore nog diffuus en ongedefinieer is, kan die student in die aanpassingsperiode op universiteit ernstige krisisse beleef wat sy identiteit en rol betref. Hierdie moontlikheid van die identiteitsproblematiek op universiteit word dikwels geïgnoreer, of uit onkunde of uit stereotiepe beskouings en onrealistiese vooroordeel teenoor die jeug. Die gevaar bestaan dat akademiese en ander sigbare prestasies die enigste norm vir beoordeling word en dat daar min insig in die problematiese lewensfase van die universiteitstudent is.

In 'n poging wat in 'n landswye ondersoek oor jeugaangeleenthede in die Republiek van Suid-Afrika gedoen is om onder andere die bewuste probleme van jongmense in die jare 16 tot 25 vas te stel, is gevind dat die terreine waarop die jeug se grootste probleme in volgorde van belangrikheid lê, die volgende is: Beroepskeuse en beroepsverrigting, finansies, die toekoms vrees daarvoor, aanpassingsprobleme ten opsigte van skool- en universiteitsvakke, huweliks- en gesinsprobleme, hofmakery, godsdienstige en morele vraagstukke, intermenslike verhoudings en sosiale wanaanpassing, swak gesondheid en geslagsprobleme. (Pieterse, pp.113-115).

Al word godsdienstige probleme nie as van die belangrikste hier aangedui nie, weet ons dat die jongmens op hierdie gebied tog ernstige probleme ondervind. Die godsdiens waarin hy groot geword het, word getoets. Volgens dr Waterink kom die probleme in verband met godsdiens veral te voorskyn in die "Weltschmerz" - 'n skuldbesef ontwaak en vergifnis word by God gesoek. Die behoefte aan aanraking met God tree sterk na vore en daar word veral na iets konkreets gesoek, hy raak krities, twyfel en worstel. Volgens gemelde ondersoek het 10,9 persent van die ondersoekgroep verklaar dat hul na godsdienstige sekerheid soek, 5,6 persent beskou hul as twyfelaars op godsdienstige gebied, 25,1 persent verklaar dat hul die godsdienstige vorme van hule kerk aanvaar het en dit as voldoende beskou en 'n verblydende 52,4 persent verklaar dat hul Jesus Christus as hul persoonlike Saligmaker en Verlosser aanvaar het. (Pieterse, p.15).

Die hele aangeleentheid van aanvaarding en uitlewing van godsdienstige waardes skep vir die adolessente student inderdaad ' $n$ probleem. As ouers in hierdie verband ' $n$ dubbele moraal gehandhaaf en nie 'n duidelike en helder voorbeeld aan hulle kinders gestel het nie, moet hulle weet dat dit ' $n$ bron van groot frustrasie by die kinders sal wees. Daar is seker niks waarteen studente so heftig reageer as juis teen die dubbele moraal van ons tyd nie. Dit werk net eenvoudig nie by ' $n$ jongmens om aan hom sekere eise te stel indien die gedrag van die persoon wat daardie eise stel se gedrag van die teenoorgestelde getuig nie. Nie alleen skiet hulle die skynheiligheid van ons volwassenes af nie, maar vernjetig ook die moontlike invloed wat ons op hulle kan hê omdat hulle ons as "straatengels" en "huisduiwels" beskou.

My raad aan ouers is: In hierdie verband bly dit ons belangrikste taak om 'n lewende voorbeeld vir ons kinders te wees. Ouers moet sorg dat hulle reg lewe en dan kan hulle dieselfde van hulle kinders verwag. Ook moet ons eerlik wees ten opsigte van ons tekortkominge en ons moet erken wanneer ons verkeerd is. Ons kan veel meer bereik deur verskoning te vra as om halsstarrig vol te hou dat ons reg is terwyl ons weet dat ons verkeerd is. Studente is intelligent, krities en wakker dit werk nie om oneerlik met hulle te wees in 'n situasie waar hulle self baie feite het nie. Die studente sien en weet wat in ons ouerhuise aangaan en hulle kan dit beoordeel. Wees eerlik met hulle. Voer gesprek en vertrou hulle.

Wanneer die psigiese en geestelike probleme van die jongmens behandel word, moet onthou word dat dit steeds verband hou met die fisiese aspekte. Daar is 'n 
voortdurende wisselwerking tussen die verskillende fasette - die een beïnvloed steeds die ander. En as die fisiese aspekte vervolgens kortliks aangeraak word, moet daar in gedagte gehou word dat dit ook in verband staan met die probleme waarna reeds verwys is.

\section{Fisiese Aspekte}

Soos die adolessensie in psigiese sin 'n oorgangstydperk is, is dit ook en veral in fisiese sin 'n veranderende tydperk. Allereers moet gedink word aan die liggaamlike veranderinge wat die jongmens ondergaan. Die kinderliggaam ontwikkel tot die volwasse gestalte, die kliere begin stowwe in die liggaam afskei wat die gemoedelikheid verstoor en onrus skep; by die seun breek die stem, sekondêre geslagskenmerke kom te voorskyn, ens.

Die jeugtydperk beteken ook 'n oorskakeling van skool na universitêre of ander opleiding of na die beroepslewe. Dit bring ook mee dat die beskermde gesinsverbintenis verruil moet word vir 'n woonplek waar veel minder beskerming en geborgenheid, indien enige, geniet word. Verlating van die ouerhuis bring 'n aansienlike vermindering van eksterne dissipline en dikwels ook 'n verlies van sekuriteit mee. Die behoefte om selfstandig te wees en onafhanklike besluite te neem, word nou miskien grootliks bevredig - die jongmens moet self besluit oor die hoeveelheid tyd wat hy aan verskillende aktiwiteite gaan wy, hy moet self besluit by watter groepe hy gaan inskakel, wat die omvang van sy sport en sosiale bedrywighede gaan wees, hoe hy sy sakgeld gaan bestee, wat die aard van sy betrekkinge met die teenoorgestelde geslag gaan wees, hoe dikwels hy die bioskoop gaan besoek of hoe dikwels hy gaan klasse bywoon.

In baie gevalle bring hierdie nuwe verantwoordelikhede benewens bevrediging egter ook 'n element van onsekerheid mee wat na buite gemanifesteer word in die vorm van eksperimentering op die verskillende terreine en na binne selfs in die vorm van angs. (Gouws, p.80).

Hierby moet in gedagte gehou word dat die student van die tagtigerjare van hierdie eeu hom in 'n tydsgees bevind wat dit nie vir hom maklik maak om sy voete te vind nie. Die tagtigerjare van hierdie eeu is 'n tydperk wat daarop ingestel is om die mens te verlaag tot ' $n$ rat in die masjien; tot 'n lewelose en meganiese "ding". Ons leef in 'n tegniese wêreld, 'n wêreld waarin die wetenskap en tegniek die wel en die wee, dit wat die mens doen en dit wat hy nie doen nie, in 'n groot mate beïnvloed; 'n gejaagde verstedelikte materialistiese wêreld wat dreig om die mens van sy menslikheid te stroop. Daarby leef ons in 'n wêreld wat gekenmerk word deur botsende ideologieë, maar ook in 'n permissiewe gemeenskap; 'n gemeenskap waarin al meer vergunnings gemaak word ten opsigte van die gedrag van die mens - vergunnings wat tot die verval van basiese beginsels en dus tot die vernietiging van die mens kan lei; 'n tyd waarin die leiers van die internasionale jeugrewolusie by die jongmens pleit om alle waardes en bindinge oorboord te gooi.

\section{Ten slotte:}

\section{Die student en sy vrees vir mislukking}

Die meeste probleme waarmee studente na die Studentediensburo kom kan na 'n kernprobleem herlei word, naamlik 'n vrees vir mislukking. Ons lewe in 'n samelewing waarin sukses die vereistes vir die reg van menslike voortbestaan geword het. En een van die belangrikste vereistes vir sukses is prestasie. Die kind het geleer dat hy deur die ouer en samelewing aanvaar word solank hy presteer. Prestasie op intellektuele en nieintellektuele vlak het vir die kind die norm geword waaraan hy sy gevoel van sukses en aanvaarding meet. Gedurende die skooljare kan die meeste kinders sodanig presteer dat hulle hulleself aanvaarbaar en suksesvol beleef. Die uitdagings op universiteit is egter veel groter. Hoër akademiese vereistes en 'n vreemde maatskaplike omgewing met groter verwagtings en uitdagings stel geweldige hoë vereistes aan die student. Hy kan nie altyd hierdie uitdagings te bowe kom soos op skool nie. Maar hy kan ook nie bekostig om daarin te misluk nie, want dan sal hy, binne die patroon waaraan hy gewoond geraak het, gevaar loop om homself as onsuksesvol en onaanvaarbaar te belewe.

Ongelukkig is dit so dat ouers dikwels direk, of nog erger, soms op 'n subtiele manier verwagtings van die kind sal hê waaraan hy nie altyd kan voldoen nie. Hoe dikwels hoor ons nie: "Onthou my kind, ek gee jou hierdie een kans in jou lewe, en as jy hierdie jaar nie deurkom nie moet jy self sien om klaar te kom" of "Pappa kry finansieel swaar, maar ons sal tog vir jou betaal al kos dit ons meer as R3 000 per jaar - jy kan mos goed doen'. Wanneer die student nou sy eerste toets druip, en dit gebeur nogal heel dikwels, ontstaan daar soveel angs vir mislukking dat die bose kringloop begin. Swak prestasie - vrees vir druip - spanning konsentrasie neem af - verder druiping van toetse vrees vir mislukkings - swakker prestasie - wat sal Ma-hulle sê - wat sal die mense sê - ek is besig om te misluk - ek is nie aanvaarbaar nie.

Nou kom die vraag wat die ouer en miskien ook die dosent kan doen om hierdie innerlike stryd van die kind wat in die meeste gevalle op ' $n$ algehele druiping uitloop, te voorkom. Dit is oor en oor bewys dat 'n kind wie se ouers hom vertrou en aanvaar soos hy is, sonder die stel van subtiele en dubbelsinnige eise met minder spanning funksioneer en beter presteer. Die goue reel van vertroue en aanvaarding van jou kind, al presteer hy nie na jou verwagtings nie, moet die ouerstudentverhouding oorkoepel. Dit is van die uiterste belang om te weet dat jou kind ' $n$ eie unieke mens is met eie vermoëns, belangstellings en doelwitte. Hy kan alleen die talente gebruik waaroor hy beskik en hy moet as sodanig aanvaar word. Daar kan nie van hom verwag word om te wees wat ander is of wat jy wil hê hy moet wees nie. Hy het die reg om te wees wat hy kan wees en om sy doelwit te bereik soos hy dit kan, al doen hy dit anders as ander studente.

Wat vir akademiese sukses geld, geld ook op alle ander terreine van die kind se lewe. Gedurende die student se studiejare is hy nie alleen in ' $n$ proses van intellektuele vorming nie, maar is hy ook besig om 'n persoonlikheidsontwikkeling te ondergaan. Hy staan in 
verhouding tot ander - sy sosiale verhouding, sy verhouding tot sy eie en die teenoorgestelde geslag en sy verhouding tot God moet op volwasse vlak vorm aanneem.

Ook hierin speel vertroue en aanvaarding 'n belangrike rol. Aanvaar u student as 'n unieke individu wat in sy maatskaplike omgewing homself moet kan wees en handhaaf. U kan nie van hom maak wat ander of uself is nie. Hy sal leer dat ander hom aanvaar soos hy is as u hom so aanvaar. Wanneer hy glo dat God hom lief het soos God hom gemaak het, sal hy glo dat ander hom ook so sal liefhê.

Watter heerlike uitdaging is dit nie om met studente te kan werk nie. Juis omdat die lewensfase waarin hulle verkeer soveel problematiek inhou, skep dit ook soveel geleenthede om te kan skep en te kan vorm. En watter bevrediging bied dit nie om te kan sien hoe die student groei en ontwikkel nie. Maar bowenal, watter bevrediging bied dit nie om te kan werk en geniet van die varsheid, die frisheid, die oorspronklikheid en die sprankel van studentwees nie, sodat ons saam met Watermeyer moet uitroep:

Julle wat die land se toekoms klop, Julle wat die trots van gister erf, Julle is die drang wat daadkrag word.

\begin{tabular}{|c|c|}
\hline & \\
\hline Nei, B.F. & $\begin{array}{l}\text { 'n Modern-Pedagogiese benadering van jeugprobleme } \\
\text { Serie Verdiepte Inzicht. Deel IX. In opdracht van de Stichting } \\
\text { Onderwys Oriëntatie, Amsterdam, Nederland. }\end{array}$ \\
\hline Kruk, R.W. & $\begin{array}{l}\text { Begeleiding der volwassewording } \\
\text { Serie Verdiepte Inzicht. Deel IX. In opdracht van de Stichting } \\
\text { Onderwys Oriënatie, Amsterdam, Nederland. }\end{array}$ \\
\hline Cronje, G. red 1965 & $\begin{array}{l}\text { Professionele Maarskaplike Werk } \\
\text { Pretoria Van Schaik. }\end{array}$ \\
\hline Pieterse, J.E. red 1968 & $\begin{array}{l}\text { Jeug en Godsdiens } \\
\text { Verslag van jeugondersoek. Deel IV. Johannesburg. Voortrek- } \\
\text { kerpers pp. } 113-115 .\end{array}$ \\
\hline Gouws, D.J. 1957 & $\begin{array}{l}\text { Die akademiese vordering en aanpassing van eerste-jaar univer- } \\
\text { siteits sfudente } \\
\text { 'n Statistiese kliniese studie. Ongepubliseerde D. Phil-proefskrif } \\
\text { U.P. }\end{array}$ \\
\hline
\end{tabular}

